\title{
A NEW ACCOUNT ON THE POTRAIT OF IBRAHIM ASMARAKANDI AND HIS SUFISM APPROACH IN ISLAMIZATION OF JAVA
}

\author{
Zumrotul Mukaffa \\ UIN Sunan Ampel, Surabaya - Indonesia | zumrotul_mukafah@yahoo.com
}

\begin{abstract}
This paper tried to show that Ibrahim Asmarakandi is one of the important preachers in the early era of Islamization in Indonesia. In addition, since Samarkandi is originated from Samarkand, the paper also tried to show the relation between Islam in Samarkand and Java in the $15 \mathrm{CE}$. Other important findings shown in the paper is that the islamization of Samarkandi has succeeded to the extent that it is accepted by both the common and elites. Interestingly, the Sufism is proven to be effective in his islamization effort. One of the key is his successful strategies, resulted from Sufism approach, is the tolerant attitudes towards other religions particularly Hindu as the biggest religion in Java at the time.
\end{abstract}

Keywords: Java, Champa, sufisme, Ibrahim Asmarakandi, Samarkand, Islamization.

\section{Introduction}

One of the greatest figure with great contribution in the success of islamisation in Java is Ibrahim Asmarakandi. He is mentioned as a Muslim intellectual as well as a Sufis who is a decendant of asmarakandi (Samarkand) ${ }^{1} \mathrm{He}$ is also popularly known as one preachers that focuses on Champa and Indonesia particularly Java. He is also the father of Raden Rahmat (Sunan Ampel), one of the famous nine saints (Sembilan wali) who also succeeded in spreading Islam not only in Java but also in Indonesia.

\footnotetext{
${ }^{1}$ Samarkand that is now is part from Uzbekistan has a great role in the islamization processes in Indonesia since the $15 \mathrm{CE}$.
} 
Ironically, his success in being one of the prominent ulama especially in the islamization efforts that also connected Samarkand, Champa and Java has been overlooked by historians. One evidence is the fact that the name of Samarkand is never mentioned as an important figure in the early islamization process in Indonesia. ${ }^{2}$ The arrival of Islam as well as its spread have always been correlated with Gujarat, Malabar, Bengal, Colomader, Persia and Saudi Arabia. ${ }^{3}$

Ibrahim Asmarakandi offers a new direction that the islamization in the early era in Indonesia actually is originated from Samarkand. Additionally, the study also shows that his approach in his preaching is Sufism. Hence, even if the result of the study does not necessarily change the commonly believed fact regarding the origin of the first spreaders of Islam in Nusantara, it will at the minimum gives the strong position for a new insight and view that Samarkhand undeniably has played an important role in the islamization process within Nusantara (Indonesia). Ibrahim, along with his family and colleagues, has been the front man in the islamization processes within Java and other areas in Indonesia since the 15 CE. Hence, it is relatively true if Samarkhand is granted an equal position with Gujarat, Malabar, Bengal, Colomander, Persia and Saudi Arabia in regards to roles of the early era of islamization in Indonesia. In addition, the study also will result in the acknowledgment of Sufism is a quite effective approach in

\footnotetext{
${ }^{2}$ Islam in the early era in Indonesia and Melayu-Nusantara is quite difficult to be put in to the periodic phases. With archeological evidences and the historical documents, historians offer diverse opinions. First one is that islam has had its early era in Indonesia and Nusantara since the 6th or \&th CE and was brought directly by the preachers from the generation of the the Prophet companions from Makkah and Madinah. The second opinions states that early era of Islam is estimated to be at the 9$11 \mathrm{CE}$ and was brought by Arab traders who stopped by Gujarat and Malabar. The third opinion stated that the beginning of Islam was at the beginning of the $14 \mathrm{CE}$ and was brought by the sufi leaders from Persia. See Azyumardi Azra, Jaringan Ulama Timur Tengah dan Kepulauan Nusantara Abad XVII dan XVIII (Bandung: Mizan, 1994); S. Q. Fatimi, Islam Comes to Malaysia (Singapore: M.S. R.I., 1963); A.H. John, "Muslim Mystics and Historitical Writings," D.G.E. Hall (ed.), Historians of South East Asia (London: Oxford University Press, 1961); G.H.W. Drewes, "New Light on the Coming of Islam to Indonesia," BKI (1968); R.O. Winstedt, "The Advant of Muhammadism in Malay Paninsula and Archipelago," JMBRAS (1971); T.W. Arnold, The Preaching of Islam: A History of Propagation of the Muslim Faith (London: Constable \& Company, 1913); Nur Syam, Islam Pesisir (Yogyakarta: LKiS, 2005).

${ }^{3}$ See for instance Husaini Husda, "Islamisasi Nusantara; Analisis Terhadap Diskursus Para Sejarawan," Adabiya, 18: 35 (August 2016): pp. 17-29.
} 
the history of the islamization processes in Indonesia. This is due to the fact that Ibrahim is a great Sufi and also due to historical facts showing that Ibrahim indeed used sufism as the approach of his preach.

\section{Ibrahim Asmarakandi: A Father of Islamizing Java}

Eventhough there is a common view that Islam begun to arrive in Indonesia since the time it developed in Macca and madina, in the period of shahaba, the historical record only found the data since the coming of Ibrahim Asmarakandi. This is evidenced by the acceptance of Javanese society, from the lower class of society to the elites, towards Islam and towards Asmarakandi as well as his decendants and here includes Sunan Ampel. Therefore, it is quite relevant to call him the pioneer and father is Islamization in java.

Ibrahim Asmarakandi or Ibrahim Al-Samarkandi is estimated to be born in the early half period of the $14 \mathrm{CE}$. He is known as the father of Raden Ali Rahmatullah who is also known as Sunan Ampel. ${ }^{4}$

Based on babad tanah Jawi, he is known as Makdum Brahim Asmara or Maulana Ibrahim Asmara. The "Asmara" or Asmarakandi seems to be a result from pronouncing it in Javanese dialek. In addition to that, it is also quite apparent that the coming of Asmarakandi to Champ, just before his coming to java, uses the trade medium in Asia centered in Samarkand.

Islamic historiography recorded clearly that Samarkand has been the important part before the $15 \mathrm{CE}$ of islami history. This can not be separated from the acceptance and also the support from the authority at the time to the development of knowledge in Samarkand. Ibnu Atsir stated in "Al-Lubab" that "bal inna al-mulüka anfusabum kānù yubibbūna

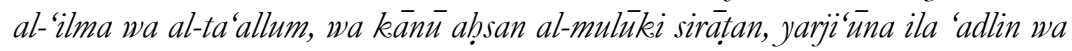
dinin wa 'ilmin". ${ }^{5}$

The authority or the rulers at the time do not merely limit their roles in running the governance but also have support for the development of knowledge.

\footnotetext{
4 Ronit Ricci, "Conversion to Islam on Java and the Book of One Thousand Questions," Bijdragen tot de Taal-, Land-en Volkenkunde, 165: 1 (2009): pp. 8-31

${ }^{5}$ Muhammad Mu'awwidl, "Muqaddimah al-Tahqiq," Abu al-Laits Nashr Muhammad bin Muhammad bin Ibrahim al-Samarqandi, Tafsir al-Samarqandi al-Musamma Babr alUlum, Vol. 1 (Beirut: Dar al-Kutub al-Ilmiyah, 1993), p. 8.
} 
The era of migration of Ibrahim Asmarakandi is estimated to happen at the era of Timurid Dinasty (1370 M-1506 M). Samarkand, particularly under Timur Lenk's authority (1336- $1405 \mathrm{M}$ ), has not only been the center of Islamic development but also the center of architectural art, modern secular science. It also plays an important role in trade within Asia and is strategic trade area connecting two continents. ${ }^{6}$ Ulugh Bek (1409-49) who replaces Timur Lenk's is popularly known for having a deep and vast knowledge in Islam as well as for his active role in knowlegde development in particular through the higher educational institution, or commonly known as Madrasah, in Samarkand. ${ }^{7}$

It is one important point of the paper is that Ibrahim Asmarakandi, unlike commonly held believe, was not Syeikh Maulana Malik Ibrahim who was popular in Muslim Nusantara as the first propagator or preacher spreading Islam in Java. ${ }^{8}$ Even within historiography of Java, Ibrahim is being identified as Maulana Malik Ibrahim. This wrong identification 'causes it complex to study his life story including his genealogy and family tree. As a matter of fact, this false also leads to another consequence that is the denial of Ibrahim Asmarakandi as a history figure on his own. Intersertingly, "the sites of graves and gate as well as the mosque chamber that exist within the archaeological area show different location as well as different era from those of of Maulana Malik Ibrahim. ${ }^{9}$

6 Dilip Hiro, Inside Central Asia, A Political and Cultural History of Uzbekistan, Turkmenistan, Kazakbstan, Kyrgyzstan, Tajikistan, Turkey, and Iran (New York: Overlook Duckworth, 2004), pp. 19-20; Thomas R. McCray, Urbekistan (Philadelphia: Chelsea House Publisher, 2004), pp. 27-28; UNESCO, Samarkand, The Place of Crossing and Synthesis of World Cultures (Paris: United Nations Educational, Scientific and Cultural Organization, 2000), p. 25.

7 Salah Zaimeche, Samarkand (Manchester: Foundation for Science and Technology, 2005), p. 8.

8 Agus Sunyoto, Wali Songo, Rekonstruksi Sejarah yang Disingkirkan (Jakarta: Transpustaka, 2011), p. 54.

9 Sunyoto, Wali Songo, p. 55. Historiography often identified Ibrahim Asmarakandi as Maulana Malik Ibrahim that resulted in the confusion and it seemd to also resourced from Babad Tanah Jawi. In Babad, it is mentioned that Maulana Malik Ibrahim that is also often called as Syeikh Maghribi is Makdum Ibrahim Asmara. Ridin Shofyan, Wasit, and Mundiri, Islamisasi di Jawa, Walisongo, Penyebar Islam di Jawa menurut Penuturan Babad (Yogjakarta: Pustaka Pelajar, 2000), p. 23; Wiji Wicaksono, Mengislamkan Tanah Jawa, Telaah Atas Metode Dakwah Walisongo (Bandung: Penerbit Mizan, 1995), p. 24. 
For example, Babad Cirebon told a story that Ibrahim is the son of Syeikh Karnen's originated from Tulen. If the data is authentic and that is the case, then it is concluded then that Ibrahim is a non aboriginal inhabitant but an emigrant who stays in Samarkand. This is due to the fact that Tulen is also frequently mentioned as "the name of Tuylen, an isle in northeast Kaspia which is a part of Kazakhtan, or specifically in northwest Samarkand area. ${ }^{10}$

Interestingly, Naskah Negarakertabhumi Sarga IV argues differently. It is mentioned in this manuscript that Ibrahim Asmarakandi has another name that is Molana Ibrahim Akbar with title of Syeikh Jatiswara. He is known as a father of Ali Musada (Ali Murtadha) and Ali Rahmatullah; the two brothers who will be know later as as Raja Pandhita or Sunan Ampel. ${ }^{11}$

In addition to the fact that it is very difficult to get certainty in defining and deciding the real or original name of Ibrahim Asmarakandi, and this is because of flaws made by Java historiography that identified him as Maulana Ibrahim, it is also even more difficult to trace his family tree. One argument is put by Jamaluddin mentioning that Ibrahim Asmarakandi is the $21^{\text {st }}$ generation of Prophet Muhammad and gives his family tree is as below:

Table 1. The First version of Genealogy of Ibrahim Asmarakandi12

1. The Prophet Muhammad SAW

2. Fatimah al-Zahra

3. Imam Husein al-Sabt

4. Ali Zainal Abidin

5. Muhammad Baqir

6. Isa al-Naqib

7. Muhammad Naqib

8. Ali Uraidi

9. Jafar Sadiq

10. Ahmad Muhajir Ilallah

11. Ubaidillah

12. Alwi

13. Muhammad

14. Alwi

\footnotetext{
${ }^{10}$ Sunyoto, $W$ ali Songo, p. 55.

11 Ibid.

12 Moch Jamaluddin Ahmad, Napak Tilas Auliya' (Jombang: Pustaka Al-Muhibbin, 2011), p. 10.
} 
15. Muhammad Sohib Marbat

16. Ali Khola' Qosam

17. Alwi

18. Amir Abdul Malik

19. Abdullah Adhomat Khan

20. Ahmad Syah Jalal

21. Maulana Jamaludin Akbar Husein

22. Ibrahim al-Samarqandi.

A different genealogy is proposed by Asmudiyaningsih who identifies that Ibrahim Asmarakandi is not Jamaluddin Akbar Husein's son; instead he is identified as Jamaluddin Jumadil Kubro's son.

Table 2. The Second version of genealogy of Ibrahim Asmarakandi13.

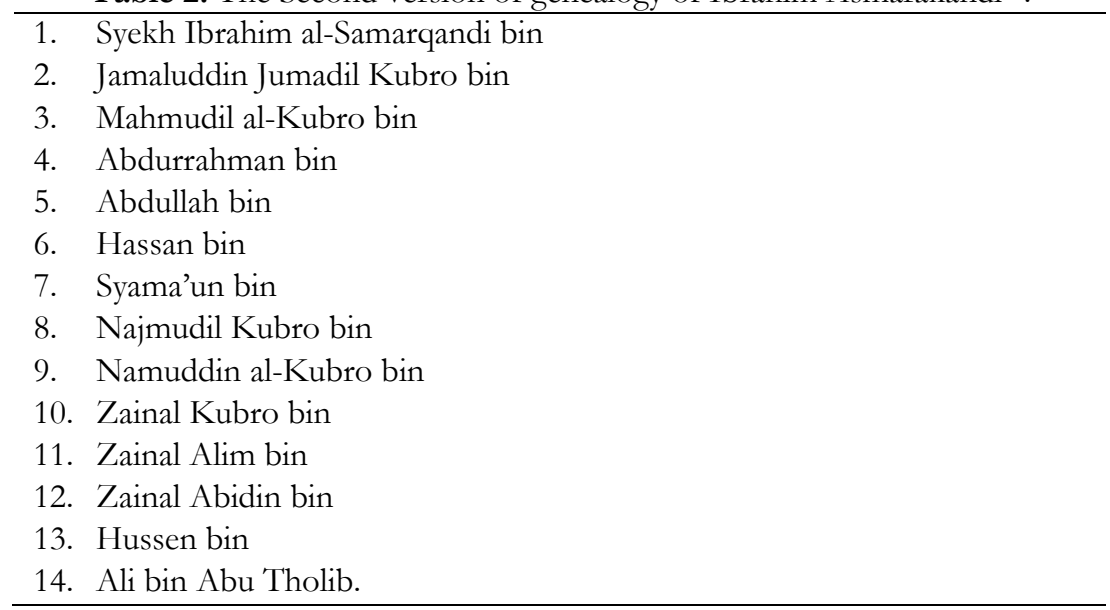

Sofwan et al. states that both Kitab Purwaka Caruban Nagari and Kitab Hikmatil Asyirah mention Syekh Ibrahim Asmarakandi as Syekh Jamaluddin Jumadil Kubro's son and Sunan Ampel's father. Here, the name of Ibrahim Asmarakandi is mentioned as Ibrahim Zainal alAkbar.

13 Asmudiyangsih, Sang Pemberi Arah dalam Sejarah (Tuban: n.p., 1996), p. 10. 
Tabel 3. The third version of Genealogy of Ibrahim Asmarakandi ${ }^{14}$

1. Nabi Muhammad Saw

2. Fatimah and Ali RA

3. Husein al-Sabti

4. Zaenal Abidin

5. Muhammad al-Baqir

6. Jakfar Saddiq

7. Kasim al-Kamil (Ali al-Uraidl)

8. Muhammad al-Nagib (Idris)

9. Isa al-Bisri (al-Baqir)

10. Ahmad al-Muhajir

11. Ubaidillah

12. Muhammad

13. Alwi

14. Ali al-Gayam (Gazam)

15. Muhammad

16. Alwi Amir Faqih

17. Abdul Malik

18. Abdullah Khan Nuddin (Amir)

19. Al Amir Ahmad Syaikh Jalalludin

20. Jamaluddin al-Husein

21. Ibrahim Zainal Akbar.

Admittedly, it is quite difficult to determine which genealogy or which data can be justified as the valid one. One of the biggest reason is the absence of document that can support each data mentioned above. To give illustration, sources that actually tells a story on biography of Maulana Jamaludin Akbar Husein, Jamaluddin Jumadil Kubro, or Jamaluddin al-Husein that are claimed as Ibrahim's father's name are almost impossible to find. This means that the family tree of Ibrahim Asmarakandi is still a mystery till recent days.

In spite of that, it is important to note that there is no single historian denies the birth of Ibrahim in Samarkand. 15 There are several

\footnotetext{
${ }^{14}$ Shofyan, Wasit, and Mundiri, Islamisasi di Jawa, pp. 38-39.

${ }^{15}$ Interestingly, different argument proposed by Nur Syam. Referring to the folklore of the people at Gisikharjo, he argued that Ibrahim was not from Samarkand. Instead, he is believed to be originated from Hadramaut Yaman. This i salso due to the similarity of ratib at the ritual of Syeikh Ibrahim Asmarakandi with that of the scholars from Hadramaut in Jakarta. See Syam, Islam Pesisir, p. 103.
} 
evidences prove that and one of them is the existence of manuscript "Usul Nem Bis" consisting six chapters that spread widely in many traditional schools (pesantren). In this manuscript, every chapter is consistently begun by "Bismillāh al-rahman al-rahim". ${ }^{16}$ This script is written by Ibrahim Asmara whose last name is verbasteering taken from the spelling of al-Samarkandi as his origin from Samarkand in middle Asia. The adding of the name of home region of the writer as the last name was common and is still common till nowadays. ${ }^{17}$

The uniformity of Sunan Ampel's genealogy also supports the assumption that Ibrahim Asmarakandi is originated from Samarkand. Here Sunyoto states as follows

"Assumption that Ibrahim al-Samarkandi is originated from Samarkand in Asia is based on three things: fact that the term Alsamarkandi is pronounced Asmarakandi, the existence of the book Usul Nem Bis, the uniformity of Sunan Ampel's genealogy. In various genealogies, the figurehas always been corrrelated with the name of Husein bin Ali bin Abi Thalib whose genesis is widely known in several big countries outside Arab particularly in Khurasan. To be noted that Khurasan in that era covered most part of middle Asia including Samarkand. ${ }^{18}$

In addition to that, the finding of Suluk Ngasmara or Asmara; a tasawuf book, which is dated in $15 \mathrm{CE}$, also supports the existing data. This Suluk is strongly believed as being written by Ibrahim Asmarakandi's which is also used by Zoetmulder (1990), as a comparative data in discussing Sunan Bonang Book. Here, Eventhough he only does the comparison between the document of Sunan Bonang Book and Suluk Ngasmara from the literature perspective, there is a quite strong indication that the writer, Mahdum Ibrahim Asmara, is the grandfather of Sunan Bonang. ${ }^{19}$

Another important historical aspect of Ibrahim Asmarakandi is the location of the grave. Most historians have the same perspective about the burial of Ibrahim Asmarakandi. Historically, after his success in Islamizing the community at Champa, he intended to open the new

\footnotetext{
16 Sunyoto, Wali Songo, p. 56.

17 Agus Sunyoto, Sunan Ampel Raja Surabaya: Membaca Kembali Dinamika Perjuangan Dakwah Islam di Jawa Abad XIV-XV M (Surabaya: Diantama, 2004), p. 52.

18 Ibid., p. 53.

19 Ibid.
} 
preaching area in java that was under the Majapahit authority at that time. He came to Java trough the Tuban harbor and moved to to the east side of harbor to begin his islamization effort in Gisik. Unfortunately, his dream to make that area as the centre of islamization has not yet realized. After staying in Gisik, he finally passed away and was buried in the beach front. The grave has always been perceived sacred by the surrounding community as well as most traditional Muslims. This grave is well known as Makam Sunan Gegesik or Sunan Gesik. ${ }^{20}$ Now, Gisik has changed into Gisikharjo which is administratively considered as area of Palang subdistrict, Tuban-East Java.

All discussions above offer very important clues that Ibrahim Asmarakandi is one of first Islam preachers in Java, whose profile and history remained unclear up to now. Java historiography which identifies and personifies Ibrahim asmarakandi as Makdum Ibrahim is mentioned to be one of the factors behind the mysteri.

This wrong personification has resulted in various historian opinions on Ibrahim's family background and genealogies. Despite that, there is one same perspective among theirs and that is Ibrahim is a preacher originated from Samarkand. Additionally, the grave that is in Gesik beach shore is also another thing agreed by most historians.

\section{Islamizing Local Elites and the Contribution of Ibrahim Asmarakandi}

There are many historiography transcripts of Islam in the first period stating that Ibrahim was successful in promoting Islam in the community and establishing Muslim community that actually bridge Samarkand, Champa, and Java. This success can not be separated from the routes he took during the activities of islamization effort he was doing. To give illustration, before he focused on Java, he stayed for long time in Champa and succeeded in establishing Muslim community in that area. After Islamizing champa, he continued his islamization in Sumatera and then finally stayed in Gisik.

The process of establishing Muslim community in Champa which involves Ibrahim Asmarakandi begun when he arrived in that area

\footnotetext{
20 Agus Sunyoto, Atlas Walisongo, Buku Pertama yang Mengungkap Walisongo sebagai Fakta Sejarah (Jakarta: Pustaka IIMaN, 2014), p. 76.
} 
around 1300 CE. ${ }^{21}$ Despite a long route he had to take to go to Champa from his origin, his journey to Champa is considered as logic considering the good relation between Turkistan and the emperor of China from Yuan Dinasty. One of evidences is the fact that by the appointment of several Turkistan persons as officials in the state's palace. In addition, it is also strongly assumed that they also build genealogical link in Champa area considering the fact that Muslim communities were already found in Champa since the 10th century. They have had their autonomy to the extent that many Indonesian and Chinese known as Islamic preacher figures became the aides of the china's emperor since the15th century. Here, One of them is the famous Laksamana Cheng Ho. ${ }^{22}$

In the $14^{\text {th }}$ to $15^{\text {th }} \mathrm{CE}$ century, Champa was known as large kingdom and was a confederation of five provinces; each is ruled by one prince. Those provinces are Indrapura, Amarawati, Vijaya, Kauthara, and Panduranga. The glory of that kingdom occured in Che Bong Nga era 1360-1390 M. Ibrahim Asmarakndi was succussful in converting him to Islam and his name was changed to Sultan Zainal Abidin. ${ }^{23}$ This area was a famous city which was visited by many

21 Bisri Mustofa, Tarikhul Auliya' (Rembang: Gama Media, 2004 ), p. 3. This data requires further study as there is also another source stating that Syeikh Ibrahim Asmarakandi was born in the second half era of the 14 CE. Sunyoto, Wali Songo, p. 54; Sunyoto, Atlas Walisongo, p. 73. In addition, according to Asrori and Rachmat, there is another source suggesting that Ibrahim was estimated to be born at 1420 CE. Purwadi and Enis Niken, Dakwah Walisongo, Penyebaran Islam Berbasis Kultural di Jawa (Yogyakarta: Panji Pustaka, 2007), p. 23.

22 Sunyoto, Sunan Ampel, p. 54.

${ }^{23}$ Unfortunately, the Champ kingdom has vanished with tragic lost from its enemies. As amatter of fact, there are also no traces left from the kingdom to be studied nowadays. Danny Wong Tze Ken, The Nguyen and Champa during 17th and 18th Century, A Study of Nguyen Foreign Relations (Paris: International Office of Champa, 2012), p. 53. After being lost to the Dei Viet, many citizens moved to other save areas and among them are moving to the south while others stayed at Delta $M$ at An Giang province which is near to the Cambodia. Wan Zailan Kamaruddin Wan Ali, Ahmad Zuhdi Ismail, and Jasamad Han, "Masyarakat Muslim Melayu Cham di Vietnam: Kajian Mengenai Isu dan Cabaran dalam Pemikiran Islam Era Globalisasi," Jati, Vol. 18 (December 2013): pp. 129-143, p. 131. Interestingly, as told by Hikayat Hasanuddin and Sejarah Melayu, the two sons of the king of Cham (Pau Kubah) who also left Champa were moving to the areas of Nusantara. One of them, Pau Liang went to stay in Aceh while the other one, Indra Berma, moved to Malaka in the Kingdom of Sultan Mansur (1458-1477). In addition, many of the Champ people migrated to areas that are now known as Muslim populated such the port areas in East java and North Sumatra. 
traders around the world in the first $15 \mathrm{CE}$ century, concluding India and middle east. ${ }^{24}$ Champa was briefly figured by Ming dinasty from China. It was proven by Cheng Ho and his troops visitation about three times. ${ }^{25}$

It is important to note that the arrival of Asmarakandi and his effort in preaching islam bothered the authority at the time. Several rulers even issued instruction to punish everyone in the area who follows or converts to Islam. He also issued instruction to punish Ibrahim. ${ }^{26}$ This condition made Ibrahim decided to stop and moved to stay in Singasari mountain which actually is still in the Champa area. He started islamizing the community in that new area. His activity, preaching islam, in this new area also cause anger among the rulers at the time who then decided to punish him with the death penalty. Fortunately, before Ibrahim was being executed, the ruler of Champa died. Another fortune for Ibrahmi is that the new king had a very different view on Islam and Ibrahim Asmarakandi. As a matter of fact, he later converted to Islam and even married off his daughter to Ibrahim. Here, Ibrahim had two sons and they are Ali Murtolo (Ali Murtadho) and Ali Rahmatullah who are now known as Raja Pandhita and Sunan Ampel. These stories can be found in Babad Tanah Jawi, Babad Risakipun Majapahit, and Babad Tjirebon. ${ }^{27}$

The success of Ibrahim Asmarakandi in becoming the inner circle of the family of the emperor was undeniably playing the important role in the helping the islam preaching in Champa. it can not be denied that Islam has already existed in that area since the $10 \mathrm{CE}$ and this was

Denys Lombard, "Champa Dipandang dari Selatan," Jurnal Terjemahan dan Tamadun Melayu, 3:1 (December 2011): pp. 3 - 11 and p. 7.

24 One of the factors that made Champ became a very strategic International International shipping line is the fact that the shpping line at the time was very difficult and dangerous. Many traders at the time, just like those from China, did not take the route directly from the Phan-rang route to Guangzhou. Rather, they chose to go along the Champa coast and avoid the dangerous areas of the Paracel Islands. This is as shown on European maritime maps until the 18th century. Lombard, "Champa Di pandang dari Selatan", p. 5.

25 Sjamsudduha et al., Sejarah Sunan Drajat dalam Jaringan Masuknya Islam di Nusantara (Surabaya: PT Bina Ilmu, 1998), p. 114.

26 Yudi AW, Babad Walisongo (Yogyakarta: Penerbit Narasi, 2013), p. 42.

27 Sunyoto, Atlas Walisongo, p. 75. 
before Ibrahim's arrival in the area. ${ }^{28}$ However, the spread was still insignficant and the spread of Islam as well as the established Muslim community was signifcantly stronger when the so called Syarif Auliya' came to the area. He is recently known as -Syarif Ibrahim Zainuddin al-Akbar. Some sources as like babad and serat state that Syarif Auliyah is Syeikh Mahdum Ibrahim Asmara or Ibrahim Asmarakandi. ${ }^{29}$

After staying in Champa for about 20 years, Ibrahim decided to open a new dakwah area and the choice was to open it in Java. One of the reasons behind this choice is the optimism that the effort would be successful because Java was mostly under the Majapahit authority at the time and there was a close relation between Champa and the kingdom of Majapahit. This is because one of the rulers of Majapahit is his wife's brother in law. Dewi Darawati, Dewi Condrowulan's younger sister, got married with Prabu Brawijaya (King of Majapahit). Babad Walisongo describes that Ibrahim's journey to Java was accompanied by big his family and here including his two sons, Raden Burereh (his nephew) as well as a number of his relatives and friends. They made a journey along Sumatera to Palembang harbour. ${ }^{30}$

In palembang, the arrival of Ibrahim was welcomed by Adipati Arya Damar. Adipati Arya Damar was actually one of the princes from Majapahit who was trusted as a ruler in Palembang. Interestingly, during their meeting, Ibrahim took a chance to have discussion about their beliefs; they are Islam and Hindu. Here, Ibrahim put emphasize on the aspect of Tasawuf and Islam spiritual that had similarities with that of Hindu. It is told in the history that Adipati Arya Damar was moved with the discussion to the extent that he finally converted to Islam and changed his name to Ario Abdullah. ${ }^{31}$ His decision to be a Muslim has undeniably opened for the spreading of Islam and the establishment of Muslim community among the elite society in

\footnotetext{
28 A strong opinion suggesting that islam has been in Champ at the $10 \mathrm{CE}$ is due to an evidence that is the Tombstone inscribed with Arabic letters Khufi that has similar structure to that found at 1039 CE in Pandurannga (Phan-Rang, the capital of Champ). Additionally, there is a historical records show that there were already Muslims live in Champ at the time Cheng Ho did his expedition to Champ at 1405. Sjamsudduha et al., Sejarah Sunan Drajat, 116.

${ }^{29}$ Sjamsudduha, Sejarah Sunan Drajat, p. 118.

30 Purwadi, Babad Tanah Jawi (Yogyakarta: Penerbit Gelombang Pasang, 2005), p. 23.

31 Sunyoto, Atlas Walisongo, p. 74.
} 
Palembang; the rulers and the nobles. Consequently, Islam was then accepted by most of the societies at the lower level of status.

Based on the report from a Portugese adventurer, Tome Pires, Ibrahim only stayed for 3 years in Palembang and then continued his journey to Java in 1443 CE. ${ }^{32}$ Here, He stayed in Gesik to continue his spreading of islam and then lived there for the rest of his life. Here, laying on stories from the natives, Nur Syam tells as follows:

Gesikharjo, according to stories told by natives, was the village visited first by Ibrahim Asmarakandi. After that, it became the first village for his islamization or preaching efforts. Syeikh Ibrahim Asmara came to the area now called as Karang Gemulung. He is told by stories to have some rest here before conyinuing his journey to other areas. It is also told that, before he continued his journey, he nggulung keloso (folded a plaited mat) and therefore that place was then called dusun Gemulung. After that, Syeikh Ibrahim went to north area and made a well over there (this well then is popularly known as Sumur Ombe). In addition, He also did some prayers overthere and raised the land around it but unfortunately that land seep in the water and therefore it was called Dusun Rembes. He continued his journey to the west area. In that area he made two wells; one in the mosque and one in the north. That area was called Gesikharjo. ${ }^{33}$

It is strongly believed that Ibrahim was successful in islamizing the society in Gesikharjo not only among the lower level of society but also the elite society here including Tuban rulers and nobles. ${ }^{34} \mathrm{Babad}$ Tuban here explains that the rulers (the regent) in that area, untill the 15th century, was Hariyo Leno. After his passing away, Then Raden Hariyo Dikoro succeede him and later he converted to islam after his daughter, Raden Ayu Hariyo Tejo is married to Syekh Ngadurrohman, the son of Syekh Jali/Syeh Jalaluddin/Kyai makam dawa/Ngalimurtolo. Since then, all regents of Tuban are Muslim. ${ }^{35}$

All the stories told above resulted in important conclusion that is the fact that Ibrahim Asmarakandi did take a very impportant role in the first islamization process both in Champa and Java. He has

\footnotetext{
32 Purwadi and Niken, Dakwah Walisongo, p. 23. Another source states that this arrival at Tuban wa around 1410 CE. Asmudianingsih, Sang Pemberi Arah, p. 14.

33 Syam, Islam Pesisir, pp. 105-106.

${ }^{34}$ Edi Sedyawati, Tuban, Kota Pelabuhan di Jalan Sutera (Jakarta: Depdikbud, 1992).

35 R. Soeparmo, Catatan Sejarah 700 Tabun Tuban (Tuban: n.p., 1983), p. 42.
} 
succeeded making islam not only spread and accepted by the common society from the low class but also by the elite society. It is evidenced by the convertion of king of Champa to be a Muslim and also by Ibrahim's marriege to his daughter, Dewi Condrowulan. Not only in champa, Ibrahim also succeeded in establishing Muslim community in Palembang. It is evidenced by the convertion of the regent of Palembang, bupati Arya Damar, to be a Muslim. The spreading of Islam in all levels and classes of Muslim society in palembang also happened in Tuban. Ibrahim and his family were successful in maintaining the good relationship with the elites and one of the strategies is by through his choice to marriege his grandchild to bupati Tuban's son.

\section{Practicing Sufism as an Approach to Islamization}

The success of Ibrahim Asmarakandi in Islamizing Champa and java cannot be separated from his Sufism approach. ${ }^{36}$ Zoetmouder's research has found that he was one of the famous Sufis in his era and even had completely compiled his book about Sufism that was wellknown by the title "Suluk ngasmara". This book was estimated to be older than the "Suluk Wujil" authored by Sunan Bonang: ${ }^{37}$
//Ngalap pawarta kang ening/ pawartane wong kang mulyal anrasani ing jatinèltafsir ing napi lan isbat/ kang satubu ning oral napi jinis wastanipun/ kapindo napi nakirab//
//Tegese- kang nampi jinis/ sejati-jatine ning ora/ apa tan ana wujudèl tegese napi nakirah/ ana lawan pinurba/ orane- kalawan tudub/ iku jatine nakirah//
//Kang ingaran napi jinis/ atuduh ing dèwekeira/ pan tan ana ing dewèkel yogja sami waskital dening basa nakirab/ nora wujud nora makdum/ pan tan keno winicara/ /

\footnotetext{
36 The sufism approach in the process of Islamization in Nusantara turn out to be not only used by Samarkand but also by his son (Sunan Ampel). As a matter of fact, there are many studies suggesting that this very approach is the key to the success of the preaching and islamization efforts of the walisongo in Java. Sunyoto, Atlas Walisongo, p. 350; Sunyoto, Walisongo, p. 91; Sunyoto, Sunan Ampel, p. 120; Wicaksono, Mengislamkan Tanah Jawa, p. 191; Sofyan, Islamisasi di Jawa, p. 191.

${ }^{37}$ Kod. 1796 Univ. Bibl. Leiden; P.J. Zoetmulder, Manunggaling Kawulo Gusti, Pantheisme dan Monisme dalam Sastra Suluk Jawa (Jakarta: PT Gramedia Pustaka, 1990), pp. 103-104.
} 
/ N Nanging si malih sirēkil sampun mboten amicaral ing roro iku raosèl iku ing aranan ora/ apan tan ana pisan/ iku kajatine suwung/ liyep datanpa tamahan//

/ / Sakatabe kang dumadi/ Ing ngaran napi nakirah/ atuduh anane- dèwe / pan dudu anane dawak/ napi jinis ingaran/ tan ana mamada iku/ lawan sipat ing pangeran//

/ Sakarone iku napil kelawan tegesè ilal iya iku wawangenèl karone sinelo-selo/ tanpa wèh yèn kumpulo/ napi roro nora kumpul/ lawan isbat ing pangeran/ /

//Yen tan mawalera malib/ nopo roro lawan isbat/ yekni kumpul ing karonèl karonē sinela-sela/ tan akèeh yèn kumpulal tegèse Ilallab iku/ iya isbat kalamiyah//

//Lir ing kalamiyah ikil inggih isbatan balak/ ngarani aranè dèwèl kalawan isbat makripat/ ana anane dawak. sampurna ujar punikul anging pangèran kang ana/ /

//Wonten kapanggih ing tulis/ lamu roro sipat ing Hyang/ yèn sampun weruh tatane-/ tubu sipat ing pangēran/ napi kalawan isbat/ saking kitab bilibipun/ pangeran kasipat adam / /

//Aran napi kang kakikil majaji iku pangēran/ johar awal ing makamēl jamane ingaran oral nora no ing pangèran/ ngadamna wujudno kupur/ kupure- patang matdahab//

//Sipat ing Hyang kang kakikil iya sipat subudiyah/ kaun ngalimun sakēhe/ majajiku ing pangèran/ kang ajal lawan ngadam/ ana ning asyira iku/ sawab dening kanyataan//

//Mangkana wujuddirēkil ingaran wujud abngall saking pangēeran wujudè I ngadamè saking pangèran/ tan ana ing dèwèknyal tegesé abangal iku/ dèning wujud lawan ngadam/ /

//Mangkana kang napi jinis/ tan kena ingaran abngal/ dène- ngadam ing wujudèl kuneng wujud ing pangèran/ gì dèdè wujud abngal/ mangkana ing wujudipun/ tan kaworan déning adam//

/ / Mangkeana wujudè yektil dudu napi lawan isbat/ karonē dudu dèwekèel yogja sami wakitaa/ dène- basa nakirah/ datan wujud tan makedum/ pan tan kena winicaral/

/ / Nanging ta mengkène- malih/ sampun ora winicara/ ing roro iku arabèl lamu wasis ing wicaral wujude kang nakirah/ wujud ing Hyang maharubur/ yèku rahsa kang sampurna/ / 
//Sampun ta sira mrih singgih/ apan ika sedya ning Hyang/ dèn weruh marang tegese-/ kang nurat pang dèreng wikan/ lawan kang gadah serat/ dèn tangguh wong ngunduh waluh/ lawan wong duduk katèla/ /

//Apuranen kang nulis nunulis/ inggih guyonan kêwala/ jar luput dèntutugakè l anenggih ing ananira/ tan wonten ing pangèran/ ing dèwèkè apan suwung/ sapisan-pisan pan ora//

//Mangkana wujudirèkil anarima lawan ngadam/ lan amare kang agawe l duk asilian tingaliral ya tak iku kawasal aningali kang andulul katon kang anduwē tingal/ /

//Sakatahe kang dumadil mokal yèn anaa dawak/ badan kalawan nyawanè / iku minangka paèsan/ ing sipat kamalullab/ badan ing manuso iku/ apan kinarya tulada//.38

Suluk Ngasmara essentially gives important direction and guidance regarding the unification. It states that the unification of a human being with God in the level of ascetic (meditation) and the singleness as well as the transcendence of God has always been and will be maintained well. At the same time, doctrine about The Creator will not sink or mingling with His creation. Although Asmarakandi's thought is almost similar to Al-Hallaj about shatahăt (spiritual ascetic), the basic idea about the existence of God and the existence of His creatures are different. There is a similarity with Al-Gazali that the God as the creator and He never needs to another. Meanwhile, the creature is creature who, unlike God, always needs to the other. God created the creature because of His Greatness and independence. God creates the creature also in order to be respected and loved. The doctrine of the Asmakarandi above is inspired by the theory of the Javanese mysticism of universal monism. This process is known as the sevel levels of emanation. However, Asmarakandi does not recognize perfect equality between God and his creation. This is called as 'single but not a single' or 'one but not one'.

The emanation of 'existence' in various forms here should not be perceived as the real and substantive 'existence'. Rather, it has to viewed as just a form of 'virtual existence'. This emanation theory consists of seven levels. The first one is (1) Abadiyah (singleness). At this stage, the absolute Substance or the nature of God has neither known individuation nor ideas. This level is also called as the level of

38 Ibid. 
hidden level. (2) The level of $W a b d a$ (one and only) is the first phase of the emanation. At that point, the nature of the God began individuated in the form of the Light of Muhammad hidden in the secret of Allah Swt (the Lord of universe). (3) The level of Wähidiyah (singleness, one only without equality, No comparison) is the second individuation. At this stage, all the ideas have been steadily in the knowledge of God. The existence of essence that comes out ('ayankharija), is in line with the the knowledge ('ayansabita). Thus, His substance and His attributes become visible. The three levels are called as inner level or secret circle. External or physical leves consist of arwăh (soul, deceased, departed spirit), mithāl (example or comparison), ajsam (bodies), and kamil (the perfect human being). Research of Zoetmulder indicates that these four levels display the permanent substance. The conception of level in order to achieve the highest perfection for a Sufi in Abraham Asmarakandi's view seems to be completely different from that of Hamzah Fansuri and al-Sumatrani Syamsuddin and Islamic Javanese. ${ }^{39}$

Consequently, the position of a creature and here includes humans as en ablio, as, having no authority to claim the him-self (truth claim of self-being), attitudes, knowledge, and behavior as the right one (always true) and has authority "to judge" another (the other self being). In every man, there is "a dependence" on another, and another one has potentiall to become "the complementary" for "that dependence". This very doctrine of emanation is the one that leads famous figures among the Sufis from previous era such as Ibn Arabi and al-Hallaj have the very tolerant attitudes towards others even those from other faiths. ${ }^{40}$

The tolerance to other religions that has already developed in Tuban can be traced back from the reception book "the Nem Bis" which is one of the works of Asmarakandi. There are many technical vocabularies originated from Hindu being adopted by the book, among them is "Hyang-Prince (The Lord of th world)" used for

39 Latifah Ratnawati, Tasamuf Kontekstual (Palembang: Dramata, 2011), pp. 20-21; Sangidu, Wachadatul Wujud, Polemik Pemikiran Sufistik Antara Hamzab Fansuri dan Syamsuddin al-Samatrani dengan Nuruddin al-Raniri (Yogyakarta: Gama Media, 2003); Simuh, Mistik Islam Kejawen Raden Ngabehi Ranggawarsita (Jakarta: Penerbit Uinversitas Indonesia, 1988).

40 Abu al-Wafa al-Ghanimi al-Taftazani, Madkhal ila al-Tasammuf al-Islämì (Cairo: Dār alThaqafah li al-Nasyar wa al-Tauzi', 1979); Jamal al-Bana, al-Ta'addudiyah fi al-Mujtama' al-Islämi (Cairo: Där al-Fikr al-Islamī, 2001). 
"Allah" (God), "sholatthe (ritual prayers and actions performed five times daily)" called as "sembahyang" (worship), "shaum" (fasting) translated to "poso", "poropendhita (Hindu priests)" is used to call "Ulama (pious Muslim)", and so forth. ${ }^{41}$ The adaptation of the technical vocabulary of Hindu such as pendhita for ulama can be argued as one clear form of the attitude of tolerance of Asmarakandi towards other religions. Arguably, such behavior play important role in helping his mission to spread Islam and made the preach quickly appreciated and accepted by the local society as they are not feeling intimidated. ${ }^{42}$

The work of Nem Bis also illustrates the importance of understanding the social context of the society. The text was originally Arabic with the outline structure consisting a question-answer model. Later, it was translated into the Javanese. As one illustration, here is one example taken from the book as follows:

Question: If you are asked, "What is faith?" then the answer is: "I believe in God, His angels, His books, His messenger, the Last Day, and that fate-for good or bad-is ordained by God Almighty.

Question: If you are asked, "How do you believe in the books?" then the answer is: "God Almighty has revealed a book for his prophet. ${ }^{43}$

According to Laffan, the structure of the book Nem Bis is very appropriate to be used as learning material for the beginner in studying Islam because they are in the forms of "easily memorized questions and answers". That was definitely easier rather than the Islamic texts in

41 Uka Tjandrasasmita, Islamic Antiquity of Sendang Duwur (Jakarta: The Archeological Foundation, 1975), p. 76.

42 Pendhita, a technical term frequently found in Nem Bis, is neither from Islam nor from Arab. Instead, it is from Hindu tradition that is rooted from sanskrit. The term pendhita is rooted from the word pandita which is an honor label for the elites within the Brahman class. They are the ones considered authoritative to read learn and interpret as well as spread the content of the Sacred and holy book, texts regarding law and ancient philosophy. Bruce M. Sullivan, Historical Dictionary of Hinduism (Maryland: Scarecrow Press, Inc., 1997); Klaus K. Klostermaier, A Concise Encyclopedia of Hinduism (Oxford: Oneworld Publications, 1998); Karel Werner, A Popular Dictionary of Hinduism (Suney: Curzon Press, 1997).

${ }^{43}$ Michael Laffan, The Makings of Indonesian Islam, Orientalism and Narration of A Sufi Past, (New Jersey: Princeton University Press, 2011), p. 33. 
the form of narrative-descriptive. ${ }^{44}$ The success of the book and the model of explanation is also supported by the fact that Asramarakandi has managed to Islamize the society from all classes within Tuban district; both the lower class as well as the elites.

Picture 1. Three layers of roof of the Tajug mosque of Ibrahim Asmarakandi

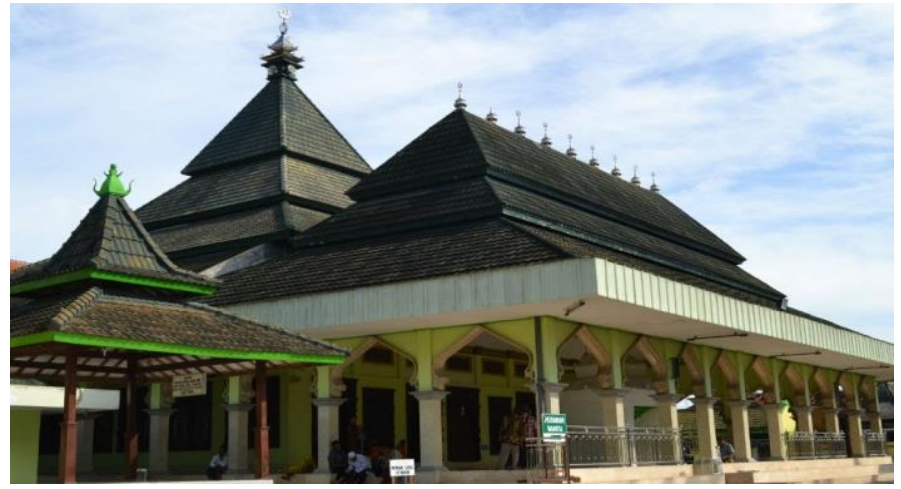

In addition to the adaptation of the technical terms from Hindu, there is also another proof showing the acceptance of Asmarakandi to local culture and that was the architecture of the Masjid (mosque) (see picture). Despite having undergone renovation several times, the mosque's architectural style is retained and unchanged from the original model. Here, as seen in the picture, the roof of the mosque, the tajug-shaped, actually represents the pyramid three layers and at the peak, there were mustoko or memolo. The construction of the building in the shape of a pyramid and mustoko are the the manifestation of Ibrahim Asmarakandi's accommodations to the style of Hindu temple during the Majapahit era in to the architecture of the mosque.

From the picture above, it is important to note that the roof that has Tajug-shape is well known as part of the Hindu temple architectural especially in Bali (Balinese meru roof) on the $15^{\text {th }}$ and $16^{\text {th }}$ CE. The tajug temple symbolically represents processes or stages in which a human takes in his journey to reach the Mahameru (The top of Semeru mountain). Mahameru is believed by the people of Hindu as the paradise or heaven. They believe that the whole kahyangan give life and human life, are on the Mahameru. Thus, the pyramid the temple,

44 Ibid., p. 38. 
eventhough is in a slimmer shape than a mosque, is the climbing process to achieve the unification with the gods in heaven. ${ }^{45}$

Interestingly, despite the adoption of the pyramid of the temple architectural style adapted by Ibrahim Asmarakandi in to the mosque, he just took three levels. And here, these three levels serving form of tajug (crown) of a mosque actually also represent the three processes or phases towards God taken from the the tradition of Sufism in Sunni Islam. In Sunni Sufism, there are three stages that must be traversed by any Muslim who wants to go reaching towards the God and they are; the Shariah (law in Islam), tariqah (path for mystics to follow esp. Sufism), and haqiqah (the truth or essence). Al-Malibari in his book Mandzumah Hidāab al-adrkiya describes the relation of the three stages. ${ }^{46}$

The book gives important clues that there are three stages a person has to take in his or her spiritual journey towards God. The three stages are a single entity that could not be separated in the process. Shari'ah (Islamic law) is illustrated as boat while the thariqah is as the ocean and the hakikat is illustrated as the pearl in the bottom of the ocean.

Here, any human who intended to take journey reaching Allah Swt (God) is described as a person who is looking for pearl in the deepest bottom of ocean, and here syariat (law in Islam) is like a boat functioning as a tool or device to be able to take journey throughout ocean, and thariqoh is like the ocean that contains pearl (diamond), while hakikat (the truth or essence) is like the pearl (diamond) which is the goal of the journey or the object has been looked for from inside the ocean. Therefore, whoever intended to look for the pearl (diamond) must make or have the boat first and here is the syariat (law in Islam). Hypothetically, if the boat is damaged or is not good it can sink in the ocean and here means the tariqah. As a consequence, they will not be able to find the pearl (diamond) or the hakikat. As a matter

45 Ashadi, Antariksa, and Purnama Salura, "Syncretism in Architectural Forms of Demak Grand Mosque," Journal of Applied Environmental and Biological Sciences, Vo. 5, No. 2 (2015), pp. 26-30. Many studies suggest that tajug of the mosque is an evidence of islam's acceptance towards hindu's architecture that is the temple. Ahmed E.I. Wahby, The Architecture of the Early Mosques and Shrines of Java: Influences of the Arab Merchants in the 15th and 16th Centuries?, Vol. 1 and 2 (Ph.D Dissertation: der FakultätGeistes und Kulturwissenschaften (GuK) der Otto-Friedrich-Universität Bamberg, 2007).

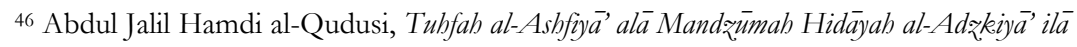
Thariq al-Auliyà' (Semarang: Penerbit Toha Putra, 1963), pp. 9-12. 
of fact, the journey as well as the person can go astray and lead astray (dillun mudillun) because he or she has too much confidence that he or she is on the right path for the search of hakikat without Syariah. More ironically, those also can mislead others. ${ }^{47}$

The process of the spiritual journey is symbolized by the three pyramids model of roof of the mosque which is believed to finally bring a human to the perfect closeness with God. In the Hindu tradition, such perfect closeness is called as mustoko or memolo while in Islamic Sufism it is known as mustaqa (see two pictures). ${ }^{48}$ In both the architecture of the mosque or Hindu temple of Asmarakandi, "mustaka" (mustaqa) is put as a symbol representing the highest achievement of a human in the presence of their Lord (Allah). In Hinduism, the highest achievement is being manifested by human who reach awareness (moksha) or get spiritual awareness (kamoksan). ${ }^{49}$

Meanwhile, according to the concept of Ibrahim Asmarakandi, reaching the spiritual awareness (moksha) is manifested into the degree of achievement of perfection of a man (al-insān al-kamil) and a holy person (waliyullah loved by Allah) who got the emanation of God's attributes. ${ }^{50}$ This is similar to the explanation that Ibrahim Asmarakandi uses the perspective of Ghazali's sufism thought who refused the concept of ittihäad, butul, and wushiul to reconstruct his perspective os sufism. His-Sufism symbolically manifested into the mustaqa mosque. This explanation is consistent with his views contained in Suluk Ngasmara that are explained previously.

\footnotetext{
47 Ibid., p. 10.

48 Wahby, The Architecture, p. 122.

${ }^{49}$ In Hindu tradition, just like in Islam, there are many ways in intepreting the journey towards the Mustaka (moksa/kamoksan). Similar to Sunni sufism tradition, the journey in Hindu tradition also requires the taking of a quite difficult path. For any person who wanted to reach moksa, he has to take the path of lelaku to reach the destination of dharma (truth), artha (wealth), kama (the desire and lust)). Kemenristek Dikti, Pendidikan Agama Hindu (Jakarta: Direktorat Jenderal Pembelajaran dan KemahasiswaanKementerian Riset, Teknologi, dan Pendidikan Tinggi Republik Indonesia, 2016), pp. 24-25. See also W. Kandi Wijaya, Panca Balikrama Besakih (Denpasar: Pustaka Larasan, 2014), p. 63. However, there are also ways to reach the Moksa trough meditation or yoga and this is mostly known among the Hindu-Budhist. Ahmad Fahruddin and Y. Hanan Pamungkas, "Siwasiddhanta Penelusuran Aliran Siwaisme di Jawa Timur Periode Klasik," Avatara, Vol. 1, No. 2 (2012): pp. 241-254, p. 249.

50 Simuh, Sufisme Jawa, Transformasi Tasawuf Islam ke Mistik. Jawa (Yogyakarta: Pustaka Pelajar, 2002), pp. 95-96.
} 
Picture 2. Mustoko/Memolo Candi ${ }^{51}$

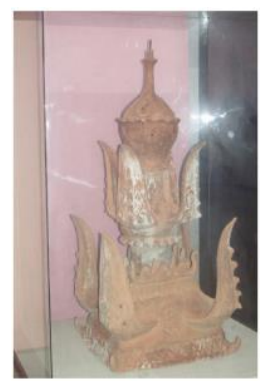

Picture 3. Mustaqa of mosque of Ibrahim Asmarakandi ${ }^{52}$

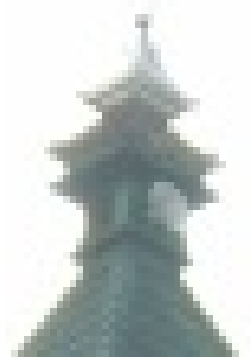

One of the most important point here is that the Sufism approach used by Ibrahim Asmarakandi which accommodates the local indigeneous tradition including the architectural style of Hindu tradition did have a great impact for the development of Islam in Java. The impact is even more apparent in the the field of architecture. Almost all the mosques built by the the early Islamic preachers in Java known as Walisongo used the pyramid-shaped roof as architectural style (tajug). This, for example, can be traced back from the architecture of mosques in Ampel Denta, Cirebon, Sendang Duwur Lamongan, Drajat, Bonang, Panjunan, Demak and Banten. Genealogically, these holy preachers are connected to Ibrahim Asmarakandi.

\section{Conclusion}

Ibrahim Asmarakandi was one the first preachers who spreaded Islam in Champa and Java. Many evidecens show that he has succeeded in Islamizing the society from all classes both the low class society to the government high officials or nobleman on both areas. Genealogically, Javanese historiography noted that he is originated from Samarkand and is from the family lineage of citizens purely "Tyulen" (Kazakhstan) who then migrated to the area that is currently located in the country of Uzbekistan.

There is only very few data that gives information about Ibrahim Asmarakandi. Consequently, there is still a high uncertainty, some will cal it mystery, in regards to the exact time and place of his birth. This

51 Wahby, The Architecture, p. 385.

52 Sunyoto, Atlas Walisongo, p. 74. 
has lead to diverse opinions among historians. Smilarly, there is also a high uncertainty in regards to his genealogic and hence there is various opinions. Neverthelless, it can be argued that he is the descendant of the Prophet Muhammad from the Husein ibn Ali Ibn Abi Talib/Fatimah. In this regads, all historians share one common agreement.

If there is a high uncertainty regarding his birth place and time as well as his genealogy, there is an agreement among historians that Ibrahim indeed had played a very important role to the efforts of Islamisation in early era, exactly in the late $14^{\text {th }}$ century and early $15^{\text {th }} \mathrm{CE}$. He was not only successfull in spreading to the lower class, but also was able to convice the local elites in Champa, Palembang and Java. One interesting point is the strategy he uses and it is the approach of Sufism.

The Sufismis is an approach that is used by Ibrahim Asmarakandi to Islamize Champa and Java. This approach tends to put him as the Muslim missionary who is tolerant of local culture, including the Hindu that has been present and growing before. In the context of IslamisationJava, Sufismas an approach can be seen of adaptation vocabulary that commonly used in Hinduism such as Hyang-Pangeran (the Lord), sembabHyang (prayer to Allah the Lord of the world), Poso (fasting), Pendhita (Hindu priest) and set forth as integral part of the Islamic doctrine that is written down in his work Nem Bis. Moreover, Sufism approach looked real on the architectural style of the building of the mosque. He did not adapt the architecture of mosques that existed in Uzbekistan, but the enshrinement of Hindu manifested into the pyramid roof construction and "mustaka, memolo, or mustaqa" as the peak.

The success of Ibrahim Asmarakandi, of course become the sign of the formation of the partnership between Samarkand, Champa, and Java. The rapid development of Islam, especially in Champa and Java is not simply the real contribution of Islamic spreaders of India and the Arabian peninsula, but also of Samarkand is now a part of Uzbekistan (Central Asia), including through Ibrahim Asmarakandi. Therefore, historical studies about Islamization in Southeast Asia, especially in Indonesia at the beginning of the era (the first period), it is proper to take into account the Samarkand as one of the resource or source. []

\section{References}

\section{Books and Articles}

Ahmad, Moch Jamaluddin. Napak Tilas Auliya'. Jombang: Pustaka AlMuhibbin, 2011. 
al-Bana, Jamal. al-Ta'addudiyah fi al-Mujtama' al-Islamī. Cairo: Där al-Fikr al-Islami, 2001.

al-Qudusi, Abdul Jalil Hamdi Tuhfah al-Ashfiyà' alà Mandzūmah Hidāyah al-Adzkiyā' ilà Thariq al-Auliyā'. Semarang: Penerbit Toha Putra, 1963.

al-Taftazani, Abu al-Wafa al-Ghanimi. Madkhal ila al-Tasawnuf al-Islami. Cairo: Dar al-Tsaqafah li al-Nasyar wa al-Tauzi', 1979.

Arnold, T.W. The Preaching of Islam: A History of Propagation of the Muslim Faith. London: Constable \& Company, 1913.

Ashadi, Antariksa, and Purnama Salura. "Syncretism in Architectural Forms of Demak Grand Mosque." Journal of Applied Environmental and Biological Sciences, Vo. 5, No. 2 (2015): pp. 2630.

Asmudiyangsih. Sang Pemberi Arah dalam Sejarah. Tuban: n.p., 1996.

AW, Yudi. Babad Walisongo. Yogyakarta: Penerbit Narasi, 2013.

Azra, Azyumardi. Jaringan Ulama Timur Tengah dan Kepulauan Nusantara Abad XVII dan XVIII. Bandung: Mizan, 1994.

Drewes, G.H.W. "New Light on the Coming of Islam to Indonesia." $B K I$ (1968).

Fahruddin, Ahmad and Y. Hanan Pamungkas. "Siwasiddhanta Penelusuran Aliran Siwaisme di Jawa Timur Periode Klasik." Avatara, Vol. 1, No. 2, (2012): pp. 241-254.

Fatimi, S. Q. Islam Comes to Malaysia. Singapore: M.S. R.I., 1963.

Hiro, Dilip. Inside Central Asia, A Political and Cultural History of Uzbekistan, Turkmenistan, Kazakhstan, Kyrgyzstan, Tajikistan, Turkey, and Iran. New York: Overlook Duckworth, 2004.

John, A.H. "Muslim Mystics and Historitical Writings." D.G.E. Hall (ed.). Historians of South East Asia. London: Oxford University Press, 1961.

Kemenristek Dikti. Pendidikan Agama Hindu. Jakarta: Direktorat Jenderal Pembelajaran dan Kemahasiswaan-Kementerian Riset, Teknologi, dan Pendidikan Tinggi Republik Indonesia, 2016.

Ken, Danny Wong Tze. The Nguyen and Champa during 17th and 18th Century, A Study of Nguyen Foreign Relations. Paris: International Office of Champa, 2012. 
Klostermaier, Klaus K. A Concise Encyclopedia of Hinduism. Oxford: Oneworld Publications, 1998.

Laffan, Michael. The Makings of Indonesian Islam, Orientalism and Narration of A Sufi Past. New Jersey: Princeton University Press, 2011.

Lombard, Denys. "Champa Dipandang dari Selatan." Jurnal Terjemahan dan Tamadun Melayu, 3:1 Disember (2011): pp. 3 - 11.

McCray, Thomas R. Uzbekistan. Philadelphia: Chelsea House Publisher, 2004.

Mustofa, Bisri. Tarikbul Auliya'. Rembang: Gama Media, 2004.

Purwadi and Enis Niken. Dakwah Walisongo, Penyebaran Islam Berbasis Kultural di Jawa. Yogyakarta: Panji Pustaka, 2007.

Purwadi, Babad Tanah Jawi. Yogyakarta: Penerbit Gelombang Pasang, 2005.

Ratnawati, Latifah. Tasawuf Kontekstual. Palembang: Dramata, 2011.

Sangidu, Wachadatul Wujud, Polemik Pemikiran Sufistik Antara Hamzah Fansuri dan Syamsuddin al-Samatrani dengan Nuruddin al-Raniri. Yogyakarta: Gama Media, 2003.

Sedyawati, Edi. Tuban, Kota Pelabuban di Jalan Sutera. Jakarta: Depdikbud, 1992.

Shofyan, Ridin, Wasit, and Mundiri. Islamisasi di Jawa, Walisongo, Penyebar Islam di Jawa menurut Penuturan Babad. Yogyakarta: Pustaka Pelajar, 2000.

Simuh. Mistik Islam Kejawen Raden Ngabebi Ranggawarsita. Jakarta: Penerbit Universitas Indonesia, 1988.

-. Sufisme Jawa, Transformasi Tasawuf Islam Ke Mistik Jawa. Yogyakarta: Pustaka Pelajar, 2002.

Sjamsudduha et al., Sejarah Sunan Drajat dalam Jaringan Masuknya Islam di Nusantara. Surabaya: PT Bina Ilmu, 1998.

Soeparmo, R. Catatan Sejarah 700 Tabun Tuban. Tuban: n.p., 1983.

Sullivan, Bruce M. Historical Dictionary of Hinduism. Maryland: Scarecrow Press, Inc., 1997.

Sunyoto, Agus. Atlas Walisongo, Buku Pertama yang Mengungkap Walisongo sebagai Fakta Sejarah. Jakarta: Pustaka IIMaN, 2014. 
---------. Sunan Ampel Raja Surabaya: Membaca Kembali Dinamika Perjuangan Dakwah Islam di Jawa Abad XIV-XV M. Surabaya: Diantama, 2004.

--------. Wali Songo, Rekonstruksi Sejarah yang Disingkirkan. Jakarta: Transpustaka, 2011.

Syam, Nur. Islam Pesisir. Yogjakarta: LKiS, 2005.

Tjandrasasmita, Uka. Islamic Antiquity of Sendang Duwur. Jakarta: The Archeological Foundation, 1975.

UNESCO. Samarkand, The Place of Crossing and Synthesis of World Cultures. Paris: United Nations Educational, Scientific and Cultural Organization, 2000.

Wahby, Ahmed E. I. The Architecture of the Early Mosques and Shrines of Java: Influences of the Arab Merchants in the 15th and 16th Centuries?, Vol. 1 and 2. Ph.D Dissertation: der Fakultät Geistes und Kulturwissenschaften $(\mathrm{GuK})$ der Otto-Friedrich-Universität Bamberg, 2007.

Wan Ali, Wan Zailan Kamaruddin, Ahmad Zuhdi Ismail, and Jasamad Han. "Masyarakat Muslim Melayu Cham di Vietnam: Kajian Mengenai Isu dan Cabaran Dalam Pemikiran Islam Era Globalisasi." Jati, Vol. 18 (December 2013): pp. 129-143.

Werner, Karel. A Popular Dictionary of Hinduism. Suney: Curzon Press, 1997.

Wicaksono, Wiji. Mengislamkan Tanah Jawa, Telaah Atas Metode Dakwah Walisongo. Bandung: Penerbit Mizan, 1995.

Wijaya, W. Kandi Panca Balikrama Besakih. Denpasar: Pustaka Larasan, 2014.

Winstedt, R.O. "The Advant of Muhammadism in Malay Paninsula and Archipelago.” JMBRAS (1971).

Zaimeche, Salah. Samarkand. Manchester: Foundation for Science and Technology, 2005.

Zoetmulder, P.J. Manunggaling Kawulo Gusti, Pantheisme dan Monisme dalam Sastra Suluk Jawa. Jakarta: PT Gramedia Pustaka, 1990. 